\title{
Profiling aerosol optical properties at the Central Asian site of Dushanbe, Tajikistan: pure dust cases
}

\author{
Julian Hofer $^{1, *}$, Dietrich Althausen ${ }^{1}$, Sabur F. Abdullaev ${ }^{2}$, Abduvosit N. Makhmudov ${ }^{2}$, \\ Bakhron I. Nazarov ${ }^{2}$, Holger Baars ${ }^{1}$, Ronny Engelmann ${ }^{1}$ and Albert Ansmann ${ }^{1}$ \\ ${ }^{1}$ Leibniz Institute for Tropospheric Research (TROPOS), Leipzig, Germany, *hofer@tropos.de \\ ${ }^{2}$ Physical Technical Institute of the Academy of Sciences of Tajikistan, Dushanbe, Tajikistan
}

\section{ABSTRACT}

Tajikistan is often affected by atmospheric mineral dust originating from various surrounding deserts. The direct and indirect radiative effects of that dust play a sensitive role in the Central Asian climate system and therefore need to be quantified. The Central Asian Dust Experiment (CADEX) provides for the first time an aerosol climatology for Central Asia based long-term aerosol profiling by ground-based lidar (PollyXT type) in Dushanbe, Tajikistan. For pure dust cases, mean depolarization(lidar) ratios of $0.23 \pm 0.03(44 \pm 3 \mathrm{sr})$ at $355 \mathrm{~nm}$ and $0.32 \pm 0.02(38 \pm 3 \mathrm{sr})$ at $532 \mathrm{~nm}$ wavelength have been measured. The mean extinctionrelated Ångström exponent was $0.18 \pm 0.15$.

\section{INTRODUCTION}

The Central Asian country Tajikistan and its neighboring countries contain vast arid regions and are located within the global dust belt reaching from the Sahara to the Gobi desert. Thus, the occurrence of dust events with a broad range of intensities is frequent in Tajikistan and whole Central Asia [1]. In this region, which is highly affected by climate change $[2,3]$, this dust has impacts ranging from radiative effects to health hazards $[4,5]$. Aerosol observations in Tajikistan are therefore highly important to understand regional and global transport of mineral dust and its effects on radiation budget, cloud formation etc. Therefore, longterm data on vertical profiles of aerosol optical properties are provided by the Central Asian Dust Experiment (CADEX).

\section{INSTRUMENTS AND METHODS}

The CADEX campaign was conducted at a field site of the Physical Technical Institute of the Academy of Sciences of Tajikistan in Dushanbe $\left(38^{\circ} 33^{\prime} 34^{\prime \prime} \mathrm{N}, 68^{\circ} 51^{\prime} 22^{\prime \prime} \mathrm{E}, 864 \mathrm{~m}\right.$ ASL) [6]. During the 18-month campaign (March 2015 to August 2016), a multiwavelength polarization Raman lidar PollyXT [7] was operated continuously for the lidar measurements. During the measurement period, strong dust events occurred several times and lofted dust layers at various altitudes were frequent, as well as dusty mixtures and pollution aerosol, especially in winter and spring $[6,8,9]$.

This contribution, however, provides a closer look at the aerosol optical properties during periods when purest dust was observed. Such periods were identified by the layer-mean particle linear depolarization ratio at $532 \mathrm{~nm}$ wavelength plus one standard deviation (of the mean within the averaging height range) being larger than 0.31 . The basis of this analysis are profiles of the optical properties retrieved at each possible night during the observation period. The profiles were manually evaluated with the Raman method [10, 11, 12]. 22 profiles fulfill the aforementioned criterion, but one case of a thin lofted layer was excluded, due to a small averaging height range and noisy extinction profiles. The mean averaging height range for the remaining 21 profiles was $1.6 \pm 0.5$ to $2.7 \pm 0.7 \mathrm{~km}$ AGL. For comparison of the layer-mean extinction-related Ångström exponent, AERONET (Aerosol Robotic Network [13]) data of the collocated AERONET CIMEL sun photometer [14] was used. The FLEXible 
PARTicle dispersion model FLEXPART [15] was used for the backward trajectory calculations.

\section{RESULTS}

The layer-mean particle linear depolarization ratio of the 21 pure dust cases ranged from $0.18 \pm 0.01$ to $0.29 \pm 0.01$ at $355 \mathrm{~nm}$ and from $0.30 \pm 0.02$ (determined by the applied selection criterion) to $0.36 \pm 0.01$ at $532 \mathrm{~nm}$ wavelength. The layer-mean lidar ratio ranged from $39 \pm 2 \mathrm{sr}$ to $49 \pm 9 \mathrm{sr}$ at $355 \mathrm{~nm}$ and from $32 \pm 2 \mathrm{sr}$ to $43 \pm 3 \mathrm{sr}$ at $532 \mathrm{~nm}$ wavelength. The layer-mean extinction-related Ångström exponent ranged from $-0.12 \pm 0.05$ to $0.46 \pm 0.14$. The means of all the values are listed in Tab. 1.

Table 1: Mean and standard deviation of layer-mean intensive parameters (particle linear depolarization ratio, lidar ratio and extinction-related Ångström exponent) of 21 dust events during the CADEX campaign.

\begin{tabular}{|l|c|c|}
\hline wavelength & $355 \mathrm{~nm}$ & $532 \mathrm{~nm}$ \\
\hline depol. ratio & $0.23 \pm 0.03$ & $0.32 \pm 0.02$ \\
\hline lidar ratio & $44 \pm 3 \mathrm{sr}$ & $38 \pm 3 \mathrm{sr}$ \\
\hline Angstr. exp. & \multicolumn{2}{|c|}{$0.18 \pm 0.15$} \\
\hline
\end{tabular}

Figure 1 shows a comparison of layer-mean Ångström exponents from lidar with column Ångström exponents from AERONET as scatter plots. The 21 cases have a smaller range in the AERONET Ångström exponent of the 440-870 nm range (Fig. 1a) than the ones of the $380-500 \mathrm{~nm}$ range (Fig. 1b). The correlation is similar in both cases, but the AERONET Ångström exponents of the 380-500 nm range (more comparable to the lidar wavelengths) are obviously distributed closer along the identity line (Fig. 1b).

Figure 2 shows examples of 7-day FLEXPART backward trajectories, which were calculated for all averaged layers. Exemplary lofted layers (Figs. 2a,b) had high accumulated resi-
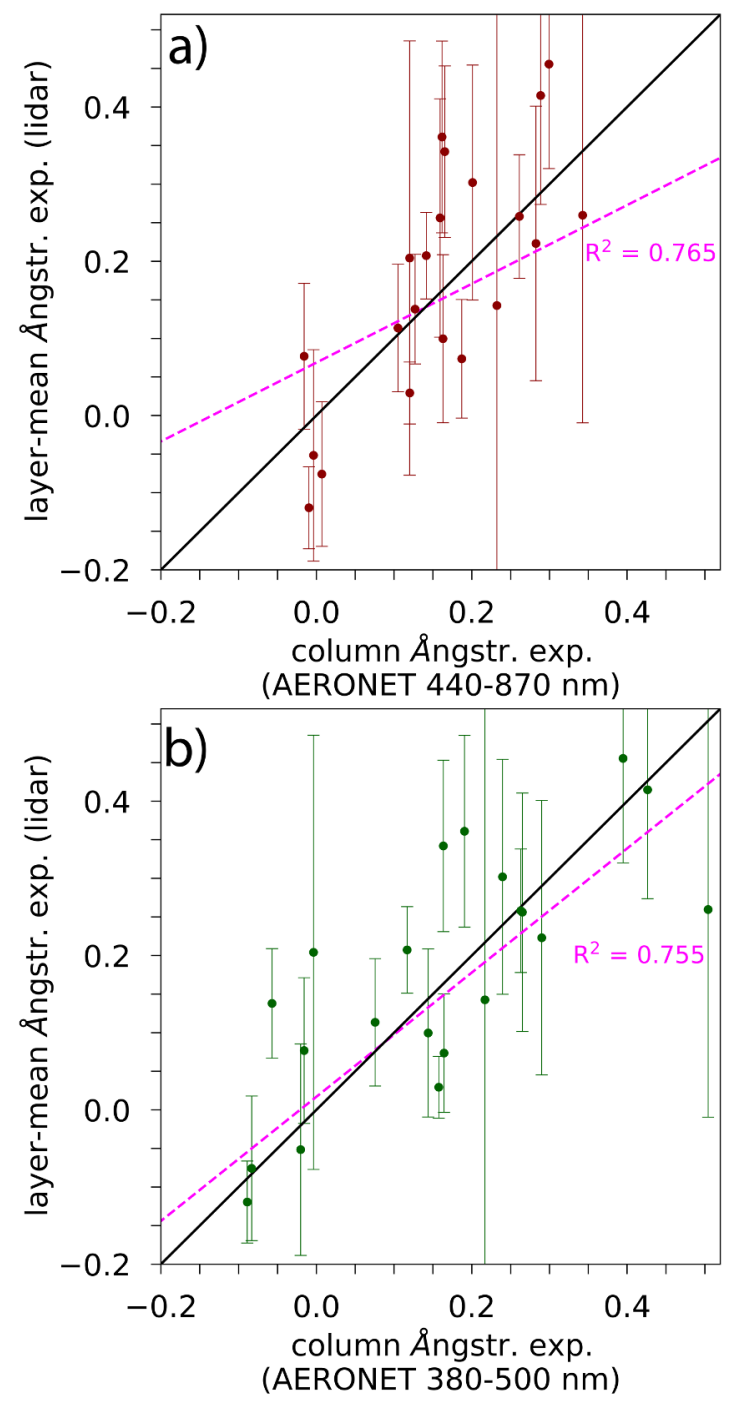

Figure 1: Comparison of layer-mean dust Angström exponents from lidar with column Angström exponents from AERONET from the 440-870 $\mathrm{nm}(\mathrm{a})$ and 380-500 $\mathrm{nm}(\mathrm{b})$ wavelength range. Errorbars indicate the standard deviation within the averaging height range.

dence times over the Arabian Peninsula, Iran and partly Afghanistan and Uzbekistan. Exemplary lower level layers had high accumulated residence times mainly in Uzbekistan and Kazakhstan towards the Caspian and Aral Sea (Figs. 2b,c). 


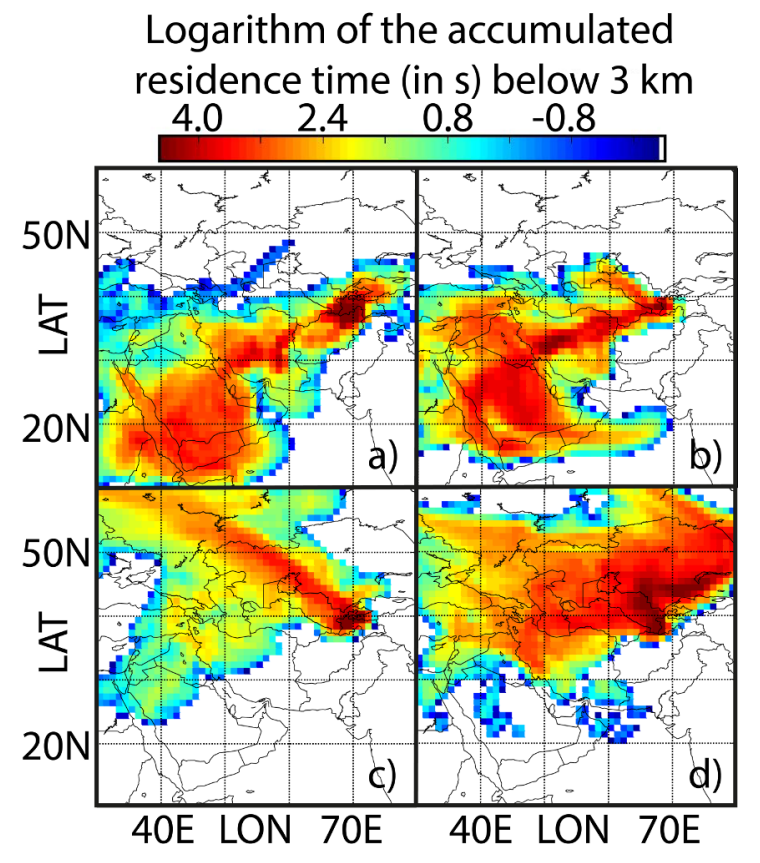

Figure 2: Accumulated residence times of 7-day FLEXPART backward trajectories arriving at Dushanbe at the following dates (UTC) and heights (AGL): a) 13 April 2015, 15:10-16:10, 2.8-3.8 km. b) 23 April 2015, 20:47-21:47, 3-5 km. c) 10 June 2015, 19:00-20:00, 1.4-2.5 km.d) 14 July 2016, 18:30-19:30, 1.4-1-8 km.

\section{CONCLUSIONS AND OUTLOOK}

The 18-month lidar observations in Dushanbe, Tajikistan, provided unprecedented data of vertical profiles of aerosol optical properties in Central Asia. The optical properties of pure dust cases observed during the CADEX campaign are presented in this study. Further analyses include the depolarization ratio, lidar ratio, Ångström exponent of all the different observed aerosol conditions as well as aerosol layer heights. The polarization-lidar photometer networking (POLIPHON) $[16,17,18]$ method will be used to estimate dust and non-dust mass concentrations, as well as concentrations of cloud condensation nuclei and ice nucleating particles on a climatological basis. For further aerosol characterization, backward trajectory analyses and AERONET data will be used in addition to the lidar data. Furthermore, forward trajectory analysis can give insights on the transport of lofted dust layers further east.

\section{ACKNOWLEDGEMENTS}

The CADEX project was funded by the German Federal Ministry of Education and Research in the context of "Partnerships for sustainable problem solving in emerging and developing countries" under the grant number 01DK14014. This project has also received funding from the European Union's Horizon 2020 research and innovation programme under grant agreement No 654109.

\section{References}

[1] Indoitu, R., Orlovsky, L., and Orlovsky, N.: Dust storms in Central Asia: Spatial and temporal variations, J. Arid Environ. 85, 62-70, (2012)

[2] Xu, H., Wang, X., and Zhang, X.: Decreased vegetation growth in response to summer drought in Central Asia from 2000 to 2012, Int. J. Appl. Earth Obs. Geoinf. 52, 390402 (2016)

[3] Lioubimtseva, E. and Henebry, G. M.: Climate and environmental change in arid Central Asia: Impacts, vulnerability, and adaptations, J. Arid Environ. 73, 963-977 (2009)

[4] Shi, Z., Xie, X., Li, X., Yang, L., Xie, X., Lei, J., Sha, Y., Liu, X.: Snow-darkening versus direct radiative effects of mineral dust aerosol on the Indian summer monsoon onset: role of temperature change over dust sources, Atmos. Chem. Phys. 19, 1605-1622 (2019)

[5] Wiggs, G. F. S., O'hara, S. L., Wegerdt, J., Van Der Meer, J., Small, I., Hubbard, R.: The dynamics and characteristics of aeolian dust in dryland Central Asia: possible impacts on human exposure and respiratory health in the Aral Sea basin, Geogr. J. 169, 142-157 (2003)

[6] Hofer, J., Althausen, D., Abdullaev, S. F., Makhmudov, A. N., Nazarov, B. I., Schettler, 
G., Engelmann, R., Baars, H., Fomba, K. W., Müller, K., Heinold, B., Kandler, K., Ansmann, A.: Long-term profiling of mineral dust and pollution aerosol with multiwavelength polarization Raman lidar at the Central Asian site of Dushanbe, Tajikistan: case studies, Atmos. Chem. Phys. 17, 14 559-14 577 (2017)

[7] Engelmann, R., Kanitz, T., Baars, H., Heese, B., Althausen, D., Skupin, A., Wandinger, U., Komppula, M., Stachlewska, I. S., Amiridis, V., Marinou, E., Mattis, I., Linné, H., Ansmann, A.: The automated multiwavelength Raman polarization and water-vapor lidar Polly ${ }^{\mathrm{XT}}$ : the neXT generation, Atmos. Meas. Tech. 9, 1767-1784 (2016)

[8] Hofer, J., Althausen, D., Abduallaev, S. F., Nazarov, B. I., Makhmudov, A. N., Baars, H., Engelmann, R., Ansmann, A.: Aerosol layer heights above Tajikistan during the CADEX campaign, Proceedings of the Central Asian Dust Conference (CADUC), Dushanbe, Tajikistan (2019)

[9] Hofer, J., Althausen, D., Abdullaev, S. F., Makhmudov, A. N., Nazarov, B. I., Schettler, G., Engelmann, R., Baars, H., Heinold, B., Müller, K., Fomba, K. W.: Central Asian Dust Experiment (CADEX): First Year Lidar Observations, in: Light, Energy and the Environment, EW2A.3, Optical Society of America (2017)

[10] Ansmann, A., Riebesell, M. A., and Weitkamp, C.: Measurement of atmospheric aerosol extinction profiles with a Raman lidar, Opt. Lett. 15, 746-748 (1990)

[11] Ansmann, A., Riebesell, M. A., Wandinger, U., Weitkamp, C., Voss, E., Lahmann, W., Michaelis, W.: Combined raman elasticbackscatter LIDAR for vertical profiling of moisture, aerosol extinction, backscatter, and LIDAR ratio, App. Phys. 55, 18-28 (1992)

[12] Ansmann, A., Wandinger, U., Riebesell, M. A., Weitkamp, C., Michaelis, W.: Independent measurement of extinction and backscatter profiles in cirrus clouds by using a combined Raman elastic-backscatter lidar, Appl. Opt. 31, 7113-7131 (1992)
[13] Holben, B. N., Eck, T. F., Slutsker, I., Tanré, D., Buis, J. P., Setzer, A., E., V., Reagan, J. A., Kaufman, Y. J., Nakajima, T., Lavenu, F., Jankowiak, I., Smirnov, A.: AERONET A Federated Instrument Network and Data Archive for Aerosol Characterization, Remote Sens. Environ. 66, 1-16 (1998)

[14] Abdullaev, S. F., Nazarov, B. I., Salikhov, T. K., Maslov, V. A.: Correlations of surface air temperature and optical thickness of arid aerosol according to AERONET data, Atmos. Ocean. Opt. 25, 428-433 (2012)

[15] Stohl, A., Forster, C., Frank, A., Seibert, P., Wotawa, G.: Technical note: The Lagrangian particle dispersion model FLEXPART version 6.2., Atmos. Chem. Phys. 5, 2461-2474 (2005)

[16] Ansmann, A. and Mamouri, R. E.: Estimated desert-dust ice nuclei profiles from polarization lidar: methodology and case studies, $A t$ mos. Chem. Phys. 15, 3463-3477 (2015)

[17] Ansmann, A. and Mamouri, R.-E.: Potential of polarization lidar to provide profiles of CCN- and INP-relevant aerosol parameters, Atmos. Chem. Phys. 16, 5905-5931 (2016)

[18] Mamouri, R.-E. and Ansmann, A.: Potential of polarization/Raman lidar to separate fine dust, coarse dust, maritime, and anthropogenic aerosol profiles, Atmos. Meas. Tech. 10, 3403-3427 (2017) 